\title{
Interaction between growth strategies and phosphorus use efficiency in grasses from South America natural grasslands ${ }^{1}$
}

\author{
Anderson Cesar Ramos Marques ${ }^{2 *}$ (D), Leandro Bittencourt de Oliveira ${ }^{3}$, Gustavo Brunetto ${ }^{4}$, Miriam da Silva \\ Tavares $^{2}$, Fernando Luiz Ferreira de Quadros ${ }^{2}$, Fernando Teixeira Nicoloso ${ }^{2}$
}

10.1590/0034-737X202067010009

\begin{abstract}
South American natural grasslands are composed of several species with different growth strategies, with variations in specific leaf area (SLA), leaf dry matter content (LDMC), specific root length (SRL) and specific root area (SRA). The objective of this study was characterizing in grasses cultivated with different levels of phosphorus $(\mathrm{P})$ in the soil if species with higher leaf and root area production per unit of dry matter have higher tissue $\mathrm{P}$ concentration, $\mathrm{P}$ use efficiency and higher dry matter yield. The plant species were grown in a greenhouse in pots with $5 \mathrm{~kg}$ of soil in a completely randomized design with four replicates and two conditions of $\mathrm{P}$ availability: addition of $60 \mathrm{mg} \mathrm{kg}^{-1}$ soil and without addition of P. The species with the highest SRA had a higher leaf and root P concentration. The higher production of leaf or root surface area per unit of dry matter did not represent higher tissue $\mathrm{P}$ use efficiency. The group formed by species of genre Paspalum had a higher leaf and root P use efficiency, therefore, areas composed of this genre are preferred for $\mathrm{P}$ fertilization.
\end{abstract}

Keywords: leaf attributes; phosphate fertilization; relative growth rate; remobilization of $\mathrm{P}$.

\section{INTRODUCTION}

Phosphorus (P) is a macronutrient that often limits plant growth worldwide (Van de Wiel et al., 2016). It is a nutrient with great importance in the transfer of metabolic energy, photosynthesis and respiration, as well as a component of nucleotides, phospholipids and phosphorylated sugars (Elanchezhian et al., 2015; Marques et al., 2019). However, in most soils, especially under tropical grasslands conditions, $\mathrm{P}$ is low available to the plants.

In natural grasslands the low $\mathrm{P}$ availability is important factor that limits the dry matter yield. In tropical and subtropical soils under natural grasslands the mainly chemical form of $\mathrm{P}_{\text {is }} \mathrm{H}_{2} \mathrm{PO}_{4}^{-}$, and under these conditions the ion is not very mobile due to the adsorption or formation of complexes with the metals iron or aluminum (Essington, 2004).

Functional attributes of leaves and roots have been commonly used to describe plant growth strategies, such as adaptations to limiting resource conditions such as nutrients and/or water in natural grasslands (Ansquer $e t$ al., 2004). They are related to the production of leaf or root surface area per unit of dry matter (Craine et al., 2001, 2005; Tjoelker et al., 2005).

The similarity between attributes of leaf and root are considered good indicators for differentiation of groups of species with contrasting growth strategies under soil $\mathrm{P}$ limitation. The main attributes of leaf used are specific

\footnotetext{
Submitted on January $16^{\text {th }}, 2019$ and accepted on November $18^{\text {th }}, 2019$

${ }^{1}$ Part of the doctoral thesis of the first author.

2 Universidade Federal de Santa Maria, Departamento de Biologia, Santa Maria, Rio Grande do Sul, Brazil. acrmarques@ hotmail.com.br; myriam_silva@hotmail.com; ftnicoloso@yahoo.com

${ }^{3}$ Universidade Regional Integrata do Alto Uruguai e das Missões, Frederico Westphalen, Rio Grande do Sul, Brazil. leandroliveira86@ hotmail.com

${ }^{4}$ Universidade Federal de Santa Maria, Departamento de Solos, Santa Maria, Rio Grande do Sul, Brazil. brunetto.gustavo@gmail.com

*Corresponding author: acrmarques@ @otmail.com.br
} 
leaf area (SLA, $\mathrm{m}^{2}$ of leaf area per $\mathrm{kg}$ of dry matter, $\mathrm{m}^{2} \mathrm{~kg}^{-1}$ ), leaf dry matter content (LDMC, dry matter per unit fresh matter, $\mathrm{g} \mathrm{kg}^{-1}$ ) and leaf $\mathrm{P}$ concentration (LPC, $\mathrm{mg} \mathrm{kg}^{-1}$ ) (Waddell et al., 2016). The main attributes of root used are specific root length (SRL, cm of root per unit of dry matter, $\mathrm{cm} \mathrm{g}^{-1}$ ), specific root area (SRA, root area per unit of dry matter, $\mathrm{cm}^{2} \mathrm{~g}^{-1}$ ) and roots $\mathrm{P}$ concentration (RPC, $\mathrm{mg} \mathrm{kg}^{-1}$ ) (Fort et al., 2015).

In a group of grasses, species with high dry matter yield under limited resource conditions, as nutrients, are characterized by high values of attributes SLA, SRL and SRA and low LDMC values (Ansquer et al., 2004; Wright et al., 2004), i.e. high yield of area or length of roots and leaves per unit of dry matter indicates that a species has attributes for a growth strategies to capture resources, as P from soil. Opposite characteristics, low values of SLA, SRL and SRA, and high values of LDMC lead the species to a low relative growth rate, due low yield of area or length of roots and leaves per unit of dry matter indicates that a species has attributes for a growth strategies to conserve the resources obtained (Wright et al., 2004).

Our hypothesis indicates that high $\mathrm{P}$ availability does not alter the leaf and root attributes related to dry matter. However, in a group of species the concentration of $\mathrm{P}$ in leaves and roots are higher for species with growth strategies to resource capture characteristics, which have higher SLA, SRE and SRL, and with lower LDMC, because they are more able to obtain $\mathrm{P}$ from the soil. Thus, species with a resource capture characteristic have a greater efficiency of $\mathrm{P}$ use in the production of dry matter of leaves and of roots, being the group with high capacity of response to fertilization when compared to species with growth strategies to resource conservation.

The objective of this study in the main grasses of South America natural grasslands was (i) characterize the change in the attributes SLA, LDMC, LPC, RPC, SRA and SRL at different levels of $\mathrm{P}$ in the soil for species with growth strategies to resource capture or resource conservation; (ii) identify if species with higher leaf and root production per unit of dry matter have higher tissue $\mathrm{P}$ concentration and $\mathrm{P}$ use efficiency; (iii) and classify the main grasses according to the attributes of leaves, roots and $\mathrm{P}$ use efficiency.

\section{MATERIALAND METHODS}

The study was carried out in the Department of Biology on the Federal University of Santa Maria (UFSM) (29 43 'S, 53 42' W), Rio Grande do Sul, Brazil. Eight grasses from South America natural grasslands with metabolic $\mathrm{C}_{4}$ pathway were chosen for this study, such as: Axonopus affinis Chase, Paspalum pumilum Nees,
Paspalum notatum Flügge, Paspalum urvillei Steudel, Paspalum plicatulum Michx, Andropogon lateralis Nees, Saccharum angustifolium Nees and Aristida laevis (Nees) Kunth.

The choice of these species was based on the representativeness of the genus and contribution in the forage dry matter for areas of natural grasslands (Bandinelli et al., 2005; Tiecher et al., 2014; Trindade et al., 2008). Before the experiment, the seedlings underwent a process of standardization. Seedlings were collected in a natural grassland on 15-July-2016. The area has no history of fertilization and correction of soil acidity, only animal grazing. After harvesting, the tillers were separated, washed and planted in plastic trays (15 liters of capacity, inclined on the table at a 20 angle to avoid accumulation of solution) containing sand as substrate and grown in greenhouse with shading of $50 \%$.

In this process, the roots were cut-off, remaining only three. The shoots were also pruned, and left with three leaves completely expanded. This process of preparation of the seedlings was repeated once a month in a greenhouse, allowing uniformity between individuals. The sand were irrigated three times a day (each tray irrigated for 15 min with ten liters of nutrient solution) with a complete nutrient solution containing (in $\mathrm{mg} \mathrm{L}^{-1}$ ) 149.80 of $\mathrm{NO}_{3}^{-} ; 24.80$ of $\mathrm{H}_{2} \mathrm{PO}_{4}^{-} ; 39.27$ of $\mathrm{SO}_{4}^{2-} ; 41.31$ of $\mathrm{Mg}^{2+}$; 288.72 of $\mathrm{Ca}^{2+} ; 234.60$ of $\mathrm{K}^{+}$; 0.03 of Mo; 0.26 of B; 0.06 of $\mathrm{Cu} ; 0.50$ of $\mathrm{Mn} ; 0.22$ of $\mathrm{Zn}$ and 4 of $\mathrm{Fe}$.

On 10-Sep-2016, the seedlings were removed from the pre-culture in sand, standardized with three roots and three leaves completely expanded and planted in pots with $5 \mathrm{~kg}$ of soil. The soil utilizated was an Ultisol, collected in the 0-20 cm layer in a natural grassland; it was air-dried and sieved in $4 \mathrm{~mm}$ mesh. The chemical characteristics of the soil were: clay, $18 \% ; 25 \mathrm{~g} \mathrm{~kg}^{-1}$ of organic matter; $\mathrm{pH}$ (water 1: 1) of 4.6; m, 30.6\%; base saturation, $26.5 \%$; effective $\mathrm{CEC}, 6.2 \mathrm{cmol}_{\mathrm{c}} \mathrm{dm}^{-3} ; 2.8 \mathrm{cmol}_{\mathrm{c}} \mathrm{dm}^{-3} \mathrm{Ca} ; 1.4 \mathrm{cmol}_{\mathrm{c}} \mathrm{dm}^{-3} \mathrm{Mg}$; $\mathrm{P}$ and $\mathrm{K}$ (Mehlich-1) were 3 and $76 \mathrm{mg} \mathrm{kg}^{-1}$, respectively. During the study, the soil was irrigated daily with distilled water to maintain field capacity at $70 \%$. The pots were distributed in a completely randomized design with four replicates in a greenhouse.

After 30 days of acclimatization of the plants, the treatments were applied, being two levels of P availability; addition of $60 \mathrm{mg} \mathrm{kg}^{-1}$ soil $\left(\mathrm{P}^{+}\right)$and a condition of low $\mathrm{P}$ availability $\left(\mathrm{P}^{-}\right)$, natural condition without the $\mathrm{P}$ application. The addition of $60 \mathrm{mg} \mathrm{P} \mathrm{kg}^{-1}$ soil increased the level of $\mathrm{P}$ availability to the high availability condition (CQFS-RS/ $\mathrm{SC}, 2016)$. $\mathrm{P}$ was applied on October 6 as $\mathrm{KH}_{2} \mathrm{PO}_{4}$. To correct the availability of the other nutrients, nitrogen $(\mathrm{N})$ was applied in the amount of $200 \mathrm{mg} \mathrm{N} \mathrm{kg}^{-1}$ of soil, $100 \mathrm{mg} \mathrm{N}$ on 06-Oct-2016 and $100 \mathrm{mg} \mathrm{N}$ on 06-Nov-2016, applied as the $\mathrm{NH}_{4} \mathrm{NO}_{3}$ and $\mathrm{KNO}_{3}$. The ratio $\mathrm{NH}_{4+}: \mathrm{NO}_{3-}$ was $30 \%: 70 \%$. 
Potassium levels were equilibrated with $\mathrm{KCl}$. All nutrients were applied by solution and weeds were manually controlled.

The plants were collected on 24-Nov-2016. For this, the soil of each pot was removed and the plants were conditioned in pots with water and stored in refrigerator in the dark for $12 \mathrm{~h}$ at $4{ }^{\circ} \mathrm{C}$. This protocol allows saturating the leaves with water before determining the leaf attributes (Cornelissen et al., 2003). The soil was sieved in a $1 \mathrm{~mm}$ mesh for the separation of the remaining roots, which were stored in a refrigerator at $4{ }^{\circ} \mathrm{C}$.

Five completely expanded leaves of each replicate were cut and weighed to determine the fresh matter of the saturated leaves. Afterwards, the leaves were scanned in an EPSON Expression 11000 scanner with 200 dpi of resolution, and the area was determined with WinRHIZO software (Regent Instruments, Quebec, Canada). The leaves were dried for $72 \mathrm{~h}$ at $60^{\circ} \mathrm{C}$ and weighed. Specific leaf area (SLA) was calculated by the ratio leaf area / leaf dry matter (Tribouillois et al., 2015). The leaf dry matter content (LDMC) was calculated by the ratio leaf dry matter / leaf fresh matter (Tribouillois et al., 2015). The rest of the leaves were reserved for dry matter (DM) of leaves determination and analysis of $\mathrm{P}$ concentration.

The roots were washed in a $1 \mathrm{~mm}$ mesh sieve with distilled water, placed in water and reserved in freezer for subsequent analysis. For analysis, the roots were suspended in $0.5 \mathrm{~cm}$ of water in a transparent acrylic tray $(30 \mathrm{~cm} \times 40 \mathrm{~cm})$ and then scanned at 600 dpi by scanner (EPSON Expression 11000). The software WinRHIZO was used to determine the total root length and root surface area. After the scanning, the root samples were dried for $72 \mathrm{~h}$ at $65^{\circ} \mathrm{C}$ and weighed to obtain dry matter (DM) of root. The attributes specific root length (SRL, root length / root DM) and specific root area (SRA, root surface area / root DM).

Leaf and root DM of each plant was milled in a Willey mill in a $1 \mathrm{~mm}$ mesh for determination of $\mathrm{P}$ by sulfuric digestion (Tedesco et al., 1995) and the concentration of P determined by the colorimetric method (Murphy \& Riley, 1962). The $P$ use efficiency was determined for leaves (PUE-L, leaves DM / P accumulated on leaves) and for roots (PUE-R, roots DM / P accumulated in roots) according to Siddiqi \& Glass (2008) methodology.

The variables were submitted to ANOVA, when the effects of the treatments were significant at $5 \%$ probability by the Test F, the differences between the means were compared by the Scott-Knott test following the two-factor model, Species $\times$ Treatment. When there was no interaction between the factors, the means comparison was done for the mean of the factors. The species were submitted to cluster analysis ( $\mathrm{p} \leq 0.15)$ using SLA, LPC, LDMC, SRL, SRA, RPC and the PUE-L and PUE-R indices with the MULTIV software (Pillar, 2001), using the Gower Index as measure of similarity.

\section{RESULTS AND DISCUSSION}

The interaction between the species and $\mathrm{P}$ fertilization factors for roots $\mathrm{P}$ concentration (RPC), specific leaf area (SLA), leaf dry matter content (LDMC), specific root area (SRA - Table 1) and P use efficiency in the roots (PUE-R - Figure 1B) was not significant, however, there was a significant difference between species $(p \leq 0.05)$. For leaf P concentration (LPC), specific root length (SRL - Table 2) and $\mathrm{P}$ use efficiency in leaves (PUE-L - Figure 1A) there was significant interaction between factors $(\mathrm{p} \leq 0.05)$.

The species $A$. affinis presented the highest SLA, while A. laevis had the lowest SLA values (Table 1). SLA of $A$. affinis was $405 \%$ higher than A. laevis, indicating higher leaf area per leaf DM unit. On the other hand, A. laevis presented the highest LDMC among all species (Table 1). A. affinis presented the lowest LDMC, 132\% lower than A. laevis. P fertilization (P) had no effect on leaf and root attributes of the species. Thus, possibly, the species presented the same pattern of carbon allocation in the cellular and tissue structures.

The species with high SLA and lower LDMC, as genre Axonopus and Paspalum, are species with higher potential for production of leaf DM in response to the $\mathrm{P}$ availability (Oliveira et al., 2018; Marques et al., 2019 - Figure 2). This is related to the ability to allocate low amount of DM per unit of leaf area (Wright et al., 2004). The species with growth strategy for resources capture need smaller amount of carbon for the production of a unit of leaf area, presenting high response to fertilization (Ansquer et al., 2004). Thus, these species produce higher leaf area per leaf DM unit, which allows them to have higher capacity of capture and assimilation of $\mathrm{CO}_{2}$ per plant, consequently, increasing its capacity to produce new leaves, and as indicated by Cruz et al. (2010) have better response to intense grazing.

Between the species, A. affinis presented the highest LPC compared to the other species (Table 2). The LPC in A. affinis was $360 \%$ higher compared to the A. lateralis species, which had the lowest LPC. The species $P$. urvillei presented the second lowest LPC (Table 2). RPC was higher for $A$. affinis and $P$. pumilum than other species. $P$. notatum, $P$. urvillei, $P$. plicatulum, A. lateralis and A. laevis were the species with the lowest values of RPC, $60 \%$ less than A. affinis and P. pumilum (Table 1).

The species $A$. affinis and $P$. pumilum showed the root system with the highest SRL in P and in $\mathrm{P}$ (Table 2). The $A$. affinis species had the highest SRA value, $131 \%$ higher than the average of species P. urvillei, P. plicatulum and $S$. angustifolium (Table 1). The highest SRA and SRL 
for $A$. affinis, independent of $\mathrm{P}$ availability, allowed this species with growth strategy for resource capture, showedto present high surface area per unit of root DM.

High surface area allows that species explore higher soil volume (Fort et al., 2015) and present higher LPC (Table 2) and RPC (Table 1). This pattern has been widely seen for certain species communities. It always appears associated to groups of species of greater SRA and SRL and characterized by a growth strategy to capture resources, showing high LPC and RPC (Craine et al., 2001; Lambers et al., 2006; Fort et al., 2015). In adiction, it is related to the high capability of response to $\mathrm{P}$ fertilization.

In $\mathrm{P}$ the PUE-L was higher for the species $P$. urvillei (Figure 1), the PUE-L was $141 \%$ larger in $P$. urvillei, when compared to the average of $P$. pumilum, $P$. notatum, $P$. plicatulum and $A$. lateralis. With $\mathrm{P}$ addition PUE-L was still higher for $P$. urvillei. The species A. affinis, P. pumilum and $P$. notatum increased the PUE-L with $\mathrm{P}$ addition, on the other hand the species A. lateralis reduced PUE-L with $\mathrm{P}$ addition. E. angustifolium and A. laevis did not alter PUE-L. For the PUE-R (Figure 1) P. notatum, P. urvillei and $P$. plicatulum presented the highest values compared to the other species, A. affinis, A. lateralis, $S$. angustifolium and $A$. laevis presented the lowest PUE-R values.

In $\mathrm{P}^{-}$leaf DM production was $0.7 \mathrm{~g}$ for each unit of increase in PUE-L (Figure 2). At $\mathrm{P}$ the leaf DM production was $1.1 \mathrm{~g}$ for each increase unit in the PUE-L, 57\% higher than P. In P for each unit of increase in PUE-R there is increase of $0.20 \mathrm{~g}$ in the root DM (Figure 2). However, at $\mathrm{P}$ for each unit of increase in the PUE-R there was an increase of $0.26 \mathrm{~g}$ of root DM, $30 \%$ more in relation to $\mathrm{P}$.

The data of the present study pointed out that, although the species $P$. notatum, $P$. urvillei, P. plicatulum, A. lateralis and $S$. angustifolium present similar values of LPC and RPC, the higher or lower P concentration in the tissue, as a result of growth strategies, not necessarily is related to higher PUE. PUE-L is higher for P. urvillei, regardless of the $\mathrm{P}$ availability (Figure 1), differently of

Table 1: Specific leaf area (SLA). leaf dry matter content (LDMC). roots P concentration (RPC) and specific root area (SRA) of eight $\mathrm{C}_{4}$ forage grasses from South America natural grasslands with different growth strategies and $\mathrm{P}$ fertilization (P and $\left.\mathrm{P}\right)$

\begin{tabular}{lcccc}
\hline Species & SLA $\left(\mathbf{m}^{\mathbf{2}} \mathbf{~ k g}^{-1}\right)$ & LDMC $\left(\mathbf{g ~ k g}^{-1}\right)$ & RPC $\left(\mathbf{m g ~ ~ ^ { - 1 } )}\right.$ & $\mathbf{S R A}\left(\mathbf{c m}^{2} \mathbf{~}^{-1}\right)$ \\
\hline Axonopus affinis & $38.4 \mathrm{a}$ & $175.1 \mathrm{f}$ & $0.5 \mathrm{a}$ & $414.1 \mathrm{a}$ \\
Paspalum pumilum & $19.1 \mathrm{c}$ & $197.5 \mathrm{e}$ & $0.4 \mathrm{a}$ & $238.2 \mathrm{~b}$ \\
Paspalum notatum & $22.5 \mathrm{~b}$ & $256.5 \mathrm{c}$ & $0.2 \mathrm{c}$ & $88.3 \mathrm{~d}$ \\
Paspalum urvillei & $17.4 \mathrm{c}$ & $220.6 \mathrm{~d}$ & $0.3 \mathrm{c}$ & $165.5 \mathrm{c}$ \\
Paspalum plicatulum & $19.0 \mathrm{c}$ & $231.2 \mathrm{~d}$ & $0.3 \mathrm{c}$ & $170.7 \mathrm{c}$ \\
Andropogon lateralis & $16.4 \mathrm{~d}$ & $301.2 \mathrm{~b}$ & $0.3 \mathrm{c}$ & $237.5 \mathrm{~b}$ \\
Saccharum angustifolium & $11.3 \mathrm{e}$ & $308.2 \mathrm{~b}$ & $0.4 \mathrm{~b}$ & $200.1 \mathrm{c}$ \\
Aristida laevis & $7.6 \mathrm{f}$ & $403.3 \mathrm{a}$ & $0.2 \mathrm{c}$ & $230.4 \mathrm{~b}$ \\
\hline Treatment & & & $0.3 \mathrm{~b}$ & 214.2 \\
\hline $\mathrm{P}^{-}$ & 18.2 & & $0.4 \mathrm{a}$ & 5.3 \\
$\mathrm{P}^{+}$ & 18.4 & 264.9 & 8.7 & \\
\hline CV $(\%)$ & 4.6 & 259.6 & 1.4 & \\
\hline
\end{tabular}

Means followed by the same letter are not statistically different by the Scott-Knott test $(\mathrm{p}>0.05)$. CV= coefficient of variation.

Table 2: Leaf $\mathrm{P}$ concentration (LPC) and specific root length (SRL) of eight $\mathrm{C}_{4}$ forage grasses from South America natural grasslands with different growth strategies and $\mathrm{P}$ fertilization $(\mathrm{P}$ and $\mathrm{P})$

\begin{tabular}{|c|c|c|c|c|}
\hline \multirow{2}{*}{ Species } & \multicolumn{2}{|c|}{ LPC (mg g $\left.\mathbf{g}^{-1}\right)$} & \multicolumn{2}{|c|}{ SRL $\left(\mathrm{cm} \mathrm{g}^{-1}\right)$} \\
\hline & P- & $\mathbf{P +}$ & P- & $\mathbf{P +}$ \\
\hline Axonopus affinis & $2.0 \mathrm{aB}$ & $2.5 \mathrm{aA}$ & $7.980 .0 \mathrm{aA}$ & $7.625 .1 \mathrm{aA}$ \\
\hline Paspalum pumilum & $0.9 \mathrm{~dB}$ & $1.1 \mathrm{dA}$ & $6.384 .5 \mathrm{aA}$ & $7.330 .5 \mathrm{aA}$ \\
\hline Paspalum notatum & $1.0 \mathrm{cB}$ & $1.3 \mathrm{cA}$ & $1.930 .6 \mathrm{dA}$ & $1.624 .1 \mathrm{dA}$ \\
\hline Paspalum urvillei & $0.7 \mathrm{eB}$ & $1.1 \mathrm{dA}$ & $4.835 .5 \mathrm{bA}$ & $4.395 .1 \mathrm{bA}$ \\
\hline Paspalum plicatulum & $1.3 \mathrm{bB}$ & $1.7 \mathrm{bA}$ & $4.700 .7 \mathrm{bA}$ & $3.915 .1 \mathrm{bA}$ \\
\hline Andropogon lateralis & $0.4 \mathrm{fB}$ & $0.7 \mathrm{eA}$ & $3.317 .1 \mathrm{cA}$ & $2.628 .9 \mathrm{cB}$ \\
\hline Saccharum angustifolium & $1.1 \mathrm{cB}$ & $1.8 \mathrm{bA}$ & $2.043 .2 \mathrm{~dB}$ & $3.510 .8 \mathrm{bA}$ \\
\hline Aristida laevis & $0.8 \mathrm{~dB}$ & $1.3 \mathrm{cA}$ & $3.107 .7 \mathrm{cB}$ & $4.614 .1 \mathrm{bA}$ \\
\hline $\mathrm{CV}(\%)$ & \multicolumn{2}{|c|}{1.4} & \multicolumn{2}{|c|}{2} \\
\hline
\end{tabular}

Same lowercase letters in columns and uppercase letters in the row do not differ statistically by the Scott-Knott test at the 5\% probability level $(\mathrm{p}>0.05)$. 
expectation, because, this species presents intermediate values of SLA and LDMC. Initially, it was expected that species with higher SLA and lower LDMC, characteristic of species more efficient in producing tissues per dry matter unit, presented higher PUE-L. The high PUE-L and PUE-R can justify the wide distribution of species of the genus Paspalum in these areas of natural grasslands, as well as the ruderal characteristic of $P$. urvillei.

Some possible explanations for the higher PUE of the genus Paspalum may be related to its physiology. Considering that $\mathrm{P}$ is involved in many aspects of plant metabolism, it is suggested that a wide range of physiological characteristics is involved in the PUE. These strategies are generally called external and internal PUEs (Van de Wiel et al., 2016).
It is possible that the external efficiency of the species of the genus Paspalum, with higher production of DM, both shoot and root, is associated with a higher $\mathrm{P}$ absorption capacity. P. Studies indicate that a high rate of $\mathrm{P}$ uptake by a species is associated with a higher relative growth rate, that is, the growth rate is responsible for regulating the uptake of $\mathrm{P}$ (Nassery, 1969; Lajtha \& Harrison, 1995). In addition, high affinity of the $\mathrm{P}$ transporters in the membrane is essential for high growth rate, and high PUE per plant, because it represents the high capacity of transport of $\mathrm{P}$ through the cellular membranes, which seems to occur in the remobilization of internal P (Elanchezhian et al., 2015).

The higher internal PUE is related to lower P requirement (Van de Wiel et al., 2016). A strategy is the
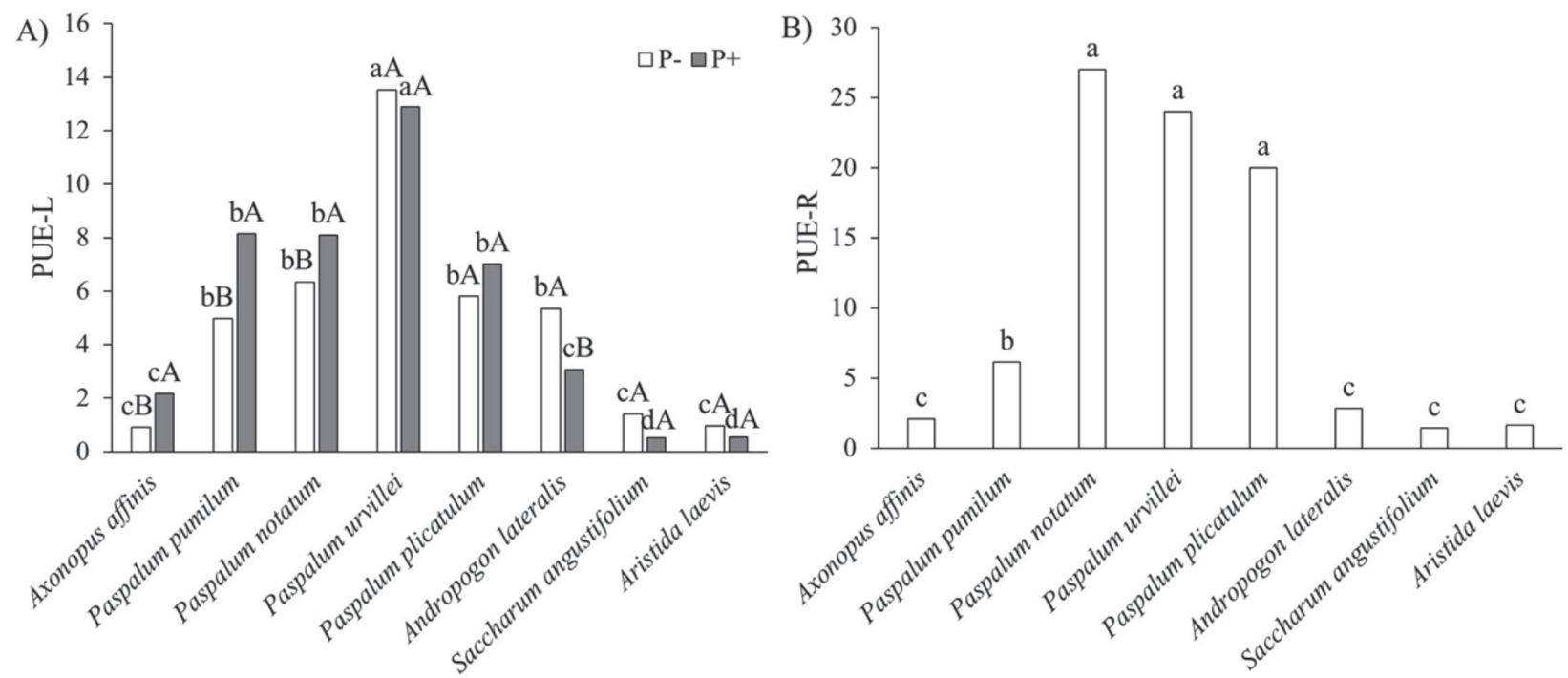

Figure 1: P use efficiency in leaves (PUE-L) (A) and P use efficiency in Roots (PUE-R) (B) for eight grasses from South America natural grasslands. Same capital letters compare treatments (P and $\mathrm{P})$ for the one species and the same lower-case letters compare species for one treatment (A); lower case letters compare species (B); same letters not differ statistically by the Scott-Knott's test $(\mathrm{p}>0.05)$.
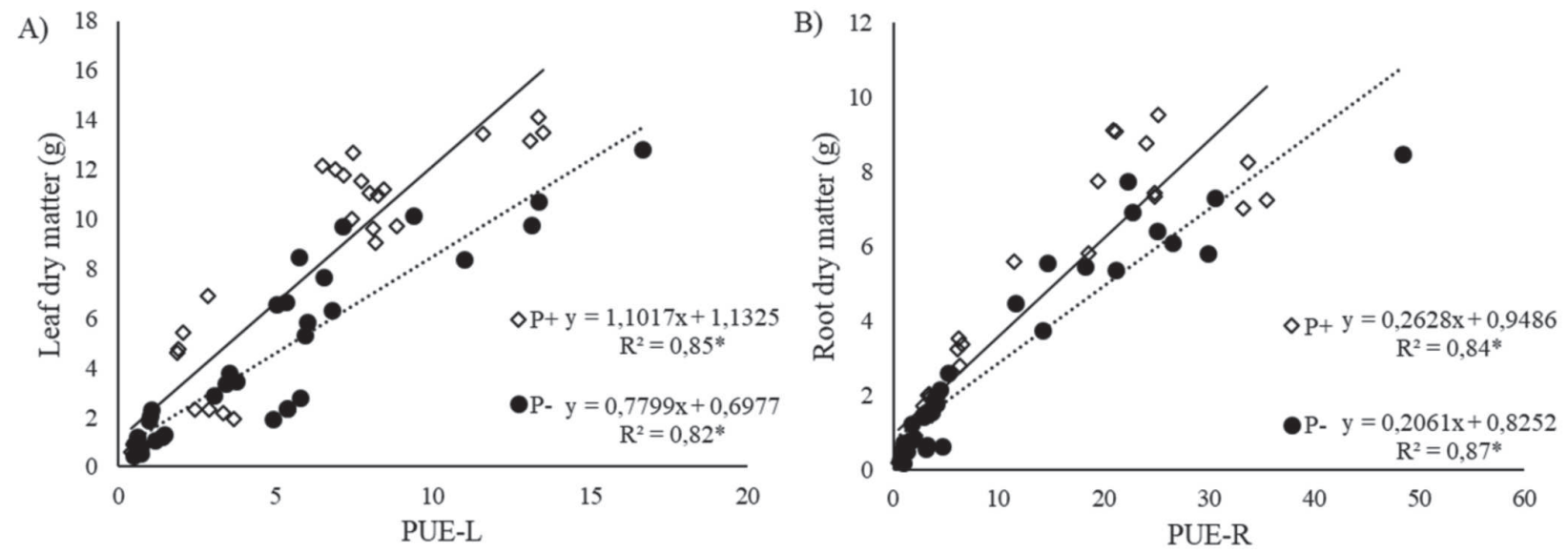

Figure 2: Correlation of leaf dry matter and $\mathrm{P}$ use efficiency in leaves (PUE-L) (A) and root dry matter and P use efficiency in root (PUE-R) (B) for eight grasses from South America natural grasslands cultivated in a condition without addition of $\mathrm{P}(\mathrm{P}-$, dotted line) and with addition of $\mathrm{P}$ in the soil $(\mathrm{P}+$, solid line). *Significant at $1 \%$ probability $(\mathrm{p} \leq 0.01)$. 
replacement of phospholipids by sulfo and / or galactolipids in the membranes, thus representing a lower allocation of $\mathrm{P}$ in structural compounds and providing $\mathrm{P}$ for energy processes (Lambers et al., 2006). In a recent study, it was shown that the low PUE of $A$. lateralis was associated with the high concentration of $\mathrm{P}$ in structural forms, such as phospholipids, and that the highest PUE by $P$. notatum was associated with $\mathrm{P}$ in soluble forms with low $\mathrm{P}$ concentration in phospholipids (Oliveira et al., 2018).

Another possible cause for high PUE is the amount of $\mathrm{P}$ allocated in RNA. Species with characteristic high PUE have presented low levels of P allocated in RNA (Sulpice et al., 2014). In a characterization of the biochemical fractions of $\mathrm{P}$, the concentration of $\mathrm{P}$ in the RNA fraction was lower in P. notatum, when compared to the species $A$. affinis and A. lateralis (Oliveira et al., 2018). Thus, the highest PUE of the species of the genus Paspalum compared to the other species, possibly, have relation with $\mathrm{P}$ use in the metabolism that is, minor use of $\mathrm{P}$ in structural compounds and use in metabolic processes in which it can not be substituted, and that has direct relation with the greater production of DM.

The formation of groups of species in this study (Table 3) aimed to transform the diversity of species of the natural grasslands of South America into smaller group of species to facilitate the use of management tools, similar, for example, that is made with grasses in Europe (Ansquer $e t$ al., 2004). When are considered the groups formed by the similarities between the three leaf attributes (SLA, LDMC and LPC), the three root attributes (SRL, RPC and SRA) and the PUE-L and PUE-R indices by cluster analysis, the species were separated into four groups with distinct characteristics $(\mathrm{p} \leq 0.15)$. The group $\mathrm{A}$, is composed exclusively of the species A. affinis ( $\mathrm{n}=8)$, a group with higher SLA, SRL, LPC, RPC and SRA. On the other hand this group has the lowest LDMC, PUE-L and PUE-R. Group B $(\mathrm{n}=8)$ is composed exclusively of the species $P$. pumilum. This group has intermediary characteristics of SLA, LDMC, LPC, SRL, RPC, SRA and PUE-R, but with a similar characteristic of PUE-L with Group C.

Group $\mathrm{C}$ has the species $P$. notatum $(\mathrm{n}=8)$, P. urvillei $(\mathrm{n}=8)$ and $P$. plicatulum $(\mathrm{n}=8)$. This group has characteristics of intermediate or low SLA, LDMC, LPC, SRL, RPC and SRA, but with high PUE-L and PUE-R. Group $\mathrm{D}$, composed of the species A. lateralis $(\mathrm{n}=8), S$. angustifolium $(\mathrm{n}=8)$ and A. laevis $(\mathrm{n}=8)$, is characterized by the higher LDMC and lower SLA, LPC, SRL, SRA, PUE-L and PUE-R. Addition of P increased LPC and RPC values independently of the group. When PUE-L is considered for the groups of species (Table 3), the species of the genus Paspalum presented the highest values. This pattern is also observed for PUE- and PUE-R and can justify the wide distribution of species of the genus Paspalum in these areas of natural grasslands, as well as the ruderal characteristic of $P$. urvillei.

When we consider the correlation between DM production and PUE (Figure 2), it is possible to observe that the high availability of $\mathrm{P}$ in the soil allows a higher

Table 3: Groups of plants formed based on attributes specific leaf area (SLA), leaf dry matter content (LDMC), leaf P concentration (LPC), specific root length (SRL), specific root area (SRA), roots P concentration (RPC) and the indices P use efficiency in leaves (PUE-L) and $\mathrm{P}$ use efficiency in roots (PUE-R) of eight $\mathrm{C}_{4}$ grasses from South America natural grasslands

\begin{tabular}{|c|c|c|c|c|c|c|c|c|}
\hline Group/Species & $\begin{array}{c}\text { SLA } \\
\left(\mathbf{m}^{2} \mathbf{k g}^{-1}\right) \\
\end{array}$ & $\begin{array}{l}\text { LDMC } \\
\left(\mathrm{g} \mathrm{kg}^{-1}\right) \\
\end{array}$ & $\begin{array}{c}\text { LPC } \\
\left(\mathrm{mg} \mathrm{kg}^{-1}\right)\end{array}$ & $\begin{array}{c}\mathrm{SRL} \\
\left(\mathrm{cm} \mathrm{g}^{-1}\right)\end{array}$ & $\begin{array}{c}\text { RPC } \\
\left(\mathrm{mg} \mathrm{kg}^{-1}\right)\end{array}$ & $\begin{array}{c}\text { SRA } \\
\left(\mathrm{cm}^{2} \mathbf{g}^{-1}\right)\end{array}$ & PUE-L & PUE-R \\
\hline A/Axonopus affinis & $38,4 \mathrm{a}$ & $175,1 \mathrm{~d}$ & $2,5 \mathrm{a}$ & $7.959,8 \mathrm{a}$ & $0,5 \mathrm{a}$ & $414,1 \mathrm{a}$ & $1,4 \mathrm{~b}$ & $2,1 \mathrm{c}$ \\
\hline B / Paspalum pumilum & $19,1 \mathrm{~b}$ & $197,5 \mathrm{c}$ & $1,1 \mathrm{~b}$ & $6.619,4 \mathrm{~b}$ & $0,4 \mathrm{ab}$ & $238,2 \mathrm{~b}$ & $7,1 \mathrm{a}$ & $6,1 \mathrm{~b}$ \\
\hline $\begin{array}{l}\mathrm{C} / \text { Paspalum notatum, } \\
\text { Paspalum urvillei, } \\
\text { Paspalum plicatulum }\end{array}$ & $19,6 \mathrm{~b}$ & $236,1 \mathrm{~b}$ & $1,2 \mathrm{~b}$ & $3.392,7 \mathrm{c}$ & $0,3 \mathrm{c}$ & $141,5 \mathrm{~d}$ & $11,1 \mathrm{a}$ & 29,9 a \\
\hline $\begin{array}{l}\mathrm{D} / \text { Andropogon lateralis, } \\
\text { Saccharum angustifolium, } \\
\text { Aristida laevis }\end{array}$ & $11,8 \mathrm{c}$ & 337,6 a & $1,1 \mathrm{~b}$ & $3.968,2 \mathrm{c}$ & $0,4 \mathrm{~b}$ & $222,7 \mathrm{c}$ & $1,5 \mathrm{~b}$ & $1,9 \mathrm{c}$ \\
\hline Treatment & & & & & & & & \\
\hline $\begin{array}{l}\mathrm{P}^{-} \\
\mathrm{P}^{+}\end{array}$ & $\begin{array}{l}18.2 \\
18.4\end{array}$ & $\begin{array}{l}264,9 \\
259,6\end{array}$ & $\begin{array}{l}1,1 \mathrm{~b} \\
1,4 \mathrm{a}\end{array}$ & $\begin{array}{l}4.287,4 \\
4.455,4\end{array}$ & $\begin{array}{l}0,3 \mathrm{~b} \\
0,4 \mathrm{a}\end{array}$ & $\begin{array}{l}214,2 \\
211,1\end{array}$ & $\begin{array}{l}4,9 \\
5,3\end{array}$ & $\begin{array}{l}10,6 \\
10,9\end{array}$ \\
\hline Source of variation & & & & & & & & \\
\hline $\begin{array}{l}\text { Group }(\mathrm{G}) \\
\text { Fertilization }(\mathrm{F}) \\
\mathrm{G} \times \mathrm{F}\end{array}$ & $\begin{array}{c}* \\
\mathrm{~ns} \\
\mathrm{~ns}\end{array}$ & $\begin{array}{l}* \\
\mathrm{~ns} \\
\mathrm{~ns}\end{array}$ & $\begin{array}{c}* \\
* \\
\mathrm{~ns}\end{array}$ & $\begin{array}{l}* \\
\mathrm{~ns} \\
\mathrm{~ns}\end{array}$ & $\begin{array}{c}* \\
* \\
\mathrm{~ns}\end{array}$ & $\begin{array}{l}* \\
\mathrm{~ns} \\
\mathrm{~ns}\end{array}$ & $\begin{array}{l}* \\
\mathrm{~ns} \\
\mathrm{~ns}\end{array}$ & $\begin{array}{l}* \\
\mathrm{~ns} \\
\mathrm{~ns}\end{array}$ \\
\hline
\end{tabular}

Means followed by the same letter in the column did not differ statistically $(\mathrm{p}>0.05)$ by the Randomization test; ns= not significant; * statistically significant. 
PUE, both in leaves and roots. This indicates that the natural condition of $\mathrm{P}$ availability in the soil of natural grasslands limits the DM yield by these species and, apparently, this should reduce mainly the dry matter yield of species of the genus Paspalum, because they are the species that most respond to $\mathrm{P}$ fertilization.

Other studies with the application of $\mathrm{P}$ in natural grasslands have demonstrated that the increased of $\mathrm{P}$ availability increased the forage yield (Gatiboni et al., 2000; Bandinelli et al., 2005; Tiecher et al., 2014), and due to the high capacity to fertilization response of genus Paspalum, the higher $\mathrm{P}$ availability allowed a high contribution of these species in forage DM, such as $P$. urvillei (Tiecher $e t$ al., 2014). Considering our data, possibly, this characteristic is related to the higher PUE by the species of the genus Paspalum.

The use of $\mathrm{P}$ fertilization is a management tool that aims to increase DM forage yield in these grasslands (Gatiboni et al., 2000; Bandinelli et al., 2005; Tiecher et al., 2014), and P fertilization does not alter the growth strategies of species within groups of species formed by these attributes, thus, the groups remain consistent even with fertilization.

In addition, areas of natural grasslands composed of genus Paspalum have high capacity to respond to $\mathrm{P}$ fertilization, and one of the main factors is the highest PUE by this species. Thus, natural grasslands in South America with large participation of Paspalum species in the forage DM should be preferable for the application of $\mathrm{P}$ fertilization as a management tool aiming high forage production. Interestingly, the classification of species by functional attributes was efficient in grouping species with similar characteristics, as already indicated, for $\mathrm{C} 3$ grasses (Ansquer et al., 2004) and C4 grasses in graze (Cruz et al., 2010), indicating to be an important tool for management of South American subtropical natural grasslands, and therefore, define the value of use of these natural grasslands according to the dominant types.

\section{CONCLUSIONS}

For South American subtropical natural grasslands, fertilization with $\mathrm{P}$ does not alter the attributes of leaves and roots related with dry matter.

The addition of $\mathrm{P}$ increases the concentration of $\mathrm{P}$ in the leaves and roots; however, species with a growth strategy for resource capture have a higher $\mathrm{P}$ concentration in the leaves and roots.

The higher yield of leaf or root surface area per dry matter unit does not represent a higher $\mathrm{P}$ efficiency.

The species $P$. pumilum, $P$. notatum, $P$. urvillei and $P$. plicatulum, with intermediate leaf attributes, have a higher $\mathrm{P}$ use efficiency use in the leaves, and P. notatum,
P. urvillei and P. plicatulum, are the species with the higher $\mathrm{P}$ use efficiency in the roots for dry matter production.

\section{ACKNOWLEDGEMENTS, FINANCIAL SUPPORT AND FULL DISCLOSURE}

The authors want to thank the Conselho Nacional de Desenvolvimento Científico e Tecnológico (CNPq) and Coordenação de Aperfeiçoamento de Pessoal de Nível Superior (CAPES), for financial support. The authors report that there is no conflict of interest in the conduct and publication of the work.

\section{REFERENCES}

Ansquer P, Theau JP, Cruz P, Viegas J, Al Haj Khaled R \& Duru M (2004) Caractérisation de la diversité fonctionnelle des prairies naturelles. Une étape vers la construction d'outils pour gérer les milieux à flore complexe. Fourrages, 179:353-368.

Bandinelli DG, Gatiboni LC, Trindade JPP, Quadros FLF de, Kaminski J, Flores JPC, Brunetto G \& Saggin A (2005) Composição floristica de pastagem natural afetada por fontes de fosforo, calagem e introdução de espécies forrageiras de estação fria. Ciência Rural, 35:84-91.

Cornelissen JHC, Lavorel S, Garnier E, Díaz S, Buchmann N, Gurvich DE, Reich PB, Steege H, Morgan HD, Heijden MGA, Van Der Pausas JG \& Poorter H (2003) A handbook of protocols for standardised and easy measurement of plant functional traits worldwide. Australian Journal of Botany, 51:335-380.

CQFS-RS/SC (2016) Manual de calagem e adubação para os estados do Rio Grande do Sul e Santa Catarina. Porto Alegre, Sociedade Brasileira de Ciência do Solo. 376p.

Craine JM, Froehle J, Tilman DG, Wedin DA, Chapin FS, Craine I \& Tilman DG (2001) The relationships among root and leaf traits of 76 grassland species and relative abundance along fertility and disturbance gradients. Oikos, 93:274-285.

Craine JM, Lee WG, Bond WJ, Williams RJ \& Johnson LC (2005) Environmental constraints on a global relationship among leaf and root traits of grasses. Ecology, 86:12-19.

Cruz P, Quadros FLF, Theau JP, Frizzo A, Jouany C, Duru M \& Carvalho PCF (2010) Leaf traits as functional descriptors of the intensity of continuous grazing in native grasslands in the south of Brazil. Rangeland Ecology \& Management, 63:350358.

Elanchezhian R, Krishnapriya V, Pandey R, Rao AS \& Abrol YP (2015) Physiological and molecular approaches for improving phosphorus uptake efficiency of crops. Current Science, 108:1271-1279.

Essington ME (2004) Soil and water chemistry: An integrative approach. Florida, CRC Press. 534p.

Fort F, Cruz P, Catrice O, Delbrut A, Luzarreta M, Stroia C \& Jouany C (2015) Root functional trait syndromes and plasticity drive the ability of grassland Fabaceae to tolerate water and phosphorus shortage. Environmental and Experimental Botany, 110:62-72.

Gatiboni LC, Kaminski J, Pellegrini JBR, Brunetto G, Saggin A \& Flores JPC (2000) Influência da adubação fosfatada e da introdução de espécies forrageiras de inverno na oferta de forragem de pastagem natural. Pesquisa Agropecuária Brasileira, 35:16631668 . 
Lajtha K \& Harrison AF (1995) Strategies of phosphorus acquisition and conservation by plants species and communities. In: Tiessen $\mathrm{H}$ (Ed.) Phosphorus in the global environment: transfers, cycles and management. Chichester, John Wiley. p.139146 .

Lambers H, Shane MW, Cramer MD, Pearse SJ \& Veneklaas EJ (2006) Root structure and functioning for efficient acquisition of phosphorus: Matching morphological and physiological traits. Annals of Botany, 98:693-713.

Marques ACR, Piccin R, Tiecher T, Oliveira LB, Kaminski J, Bellinaso RJS, Krug AV, Gatiboni LC, Quadros FLF, Carranca C \& Brunetto G (2019) Phosphorus fractionation in grasses with different resource-acquisition characteristics in natural grasslands of South America. Journal of Tropical Ecology, 01-10.

Murphy J \& Riley JP (1962) A modified single solution method for the determination of phosphate in natural waters. Analytica Chimica Acta, 27:31-36.

Nassery H (1969) Phosphate absorption by plants from habitats of different phosphate status I-Absorption and incorporation of phosphate. New Phytologist, 69:13-20.

Oliveira LB, Marques ACR, Quadros FLF, Farias JG, Piccin R, Brunetto G \& Nicoloso FT (2018) Phosphorus allocation and phosphatase activity in grasses with different growth rates. Oecologia, 186:633-643.

Pillar VD (2001) Multivariate exploratory analysis, randomization testing and bootstrap resampling. Porto Alegre, User's Guide. $41 \mathrm{p}$.

Siddiqi MY \& Glass ADM (2008) Utilization index: A modified approach to the estimation and comparison of nutrient utilization efficiency in plants. Journal of Plant Nutrition, 04:289-302.

Sulpice R, Ishihara H, Schlereth A, Cawthray GR, Encke B, Giavalisco P, Ivakov A, Arrivault S, Jost R, Krohn N, Kuo J, Lalibert E, Pearse SJ, Raven JA, Scheible WR, Teste F, Veneklaas EJ, Stitt M \& Lambers H (2014) Low levels of ribosomal RNA partly account for the very high photosynthetic phosphorususe efficiency of Proteaceae species. Plant, Cell \& Environment, 37:1276-1298.
Tedesco MJ, Gianello C, Bissani CA, Bohnen H \& Volkweiss SJ (1995) Análise de solo, plantas e outros materiais. $2^{\text {nd }}$ ed. Porto Alegre, Universidade Federal do Rio Grande do Sul. 174p.

Tiecher T, Oliveira LB, Rheinheimer DS, Quadros FLF, Gatiboni LC, Brunetto G \& Kaminski J (2014) Phosphorus application and liming effects on forage production, floristic composition and soil chemical properties in the Campos biome, southern Brazil. Grass and Forage Science, 69:567-579.

Tjoelker MG, Craine JM, Wedin D, Reich PB \& Tilman D (2005) Linking leaf and root trait syndromes among 39 grassland and savannah species. New Phytologist, 167:493-508.

Tribouillois H, Fort F, Cruz P, Charles R, Flores O, Garnier E \& Justes E (2015) A Functional characterization of a wide range of cover crop species: Growth and nitrogen acquisition rates, leaf traits and ecological strategies. Plos One, 10:01-13.

Trindade JPP, Quadros FLF \& Pillar VD (2008) Grassland vegetation of sandy patches of Rio Grande do Sul under grazing and exclosure. Pesquisa Agropecuária Brasileira, 43:771-779.

Van de Wiel CCM, Van der Linden CG \& Scholten OE (2016) Improving phosphorus use efficiency in agriculture: opportunities for breeding. Euphytica, 207:01-22.

Waddell HA, Simpson RJ, Lambers H, Henderson B, Ryan MH, Garden DL \& Richardson AE (2016) Phosphorus-utilization efficiency and leaf-morphology traits of Rytidosperma species (wallaby grasses) that differ in their growth response to phosphorus fertilization. Australian Journal of Botany, 64:6576.

Wright IJ, Reich PB, Westoby M, Ackerly DD, Baruch Z, Bongers F, Cavender-Bares J, Chapin T, Cornelissen JHC, Diemer M, Flexas J, Garnier E, Groom PK, Gulias J, Hikosaka K, Lamont BB, Lee T, Lee W, Lusk C, Midgley JJ, Navas ML, Niinemets U, Oleksyn J, Osada N, Poorter H, Poot P, Prior L, Pyankov VI, Roumet C, Thomas SC, Tjoelker MG, Veneklaas EJ \& Villar R (2004) The worldwide leaf economics spectrum. Nature, 428:821-827. 